\title{
Tasavvuf Psikolojisinin Dindarlığın Tecrübî Boyutu Kapsamında Değerlendirilmesi ve Yeni Bir Tanım İhtiyac1
}

\section{Muhammet Cevat Acar*}

Atıf/@: Acar, Muhammet Cevat, Tasavvuf Psikolojisinin Dindarlığın Tecrübî Boyutu Kapsamında Değerlendirilmesi ve Yeni Bir Tanım İhtiyacı, Artuklu Akademi 2019/6 (2), 209-228.

Öz: Ülkemizde köklü bir geçmişe ve geniş bir gruba hitap eden tasavvuf, din psikolojisi açısından oldukça zengin verilerin bulunduğu bir alandır. Ancak tasavvufi yaşam içerisindeki dinamiklerin din psikolojisi bağlamında hangi yöntem ve teknikler aracılığı ile incelenip araştırılacağı henüz net olarak belirgin değildir. Bu çalışmanın amacı, din psikolojisinde merkezi bir kavram olarak kabul edilen dindarlığın tecrübi boyutunun, tasavvuf psikolojisi çalışmaları için bir hareket noktası olarak alınıp alınamayacağını tartışmaktır. Bu amaçla özellikle dini tecrübe, mistik tecrübe ve tasavvufi tecrübe kavramları aktarılmıştır. Ardından tasavvuf psikolojisinin dindarlığın tecrübi boyutu içerisinde çalışılmasını gerektirecek argümanlar tartışılmıştır. Son olarak ise tasavvuf psikolojisinin din psikolojisinin bir alt alanı olarak kabul edilmesinin gerekliliği vurgulanarak alanda çalışan araştırmacı ve akademisyenler için tasavvuf psikolojisi kavramının yeni bir tanımı yapılmıştır.

Anahtar Kelimeler: Din psikolojisi, tasavvuf psikolojisi, dindarlığın tecrübî boyutu, dinî tecrübe, dindarlık.

\section{The Evaluation of Sufi Psychology within the Experiential Dimension of Religiosity and the Need for a New Definition}

Citation/( $:$ Acar, Muhammet Cevat, The Evaluation of Sufi Psychology within the Experiential Dimension of Religiosity and the Need for a New Definition, Artuklu Akademi 2019/6 (2), 209-228.

Abstract: Sufism with a long and deep-root history targets a large group in Turkey today. Sufism is an area providing rich data for psychology of religion studies. Although its importance, it is not clear on what kind of methods and techniques should be used in order to analyse and explore the dynamics of mystical life for the psychology of religion studies.

* Dr. Öğr. Üyesi, Mardin Artuklu Üniversitesi Edebiyat Fakültesi Psikoloji Bölümü, mcacar@artuklu.edu.tr 


\begin{abstract}
The aim of this study is to discuss whether the experiential dimension, accepted as a key concept in the psychology of religion, can be taken as a starting point for the studies of Sufi Psychology in the future. To achieve this goal, firstly, the frame work and the concept of religious, mystical and Sufi experience are explained. Then, the argument that the study of Sufi psychology should be studied within scope of experiential dimension of religiousness is discussed. Finally, by emphasizing the necessity of accepting psychology of Sufism as a subarea of the psychology of religion, a new definition for the Sufi psychology is proposed for the researchers and academics working in the field.
\end{abstract}

[The Extended Abstract is at the end of the article.]

\title{
Giriş
}

Din psikolojisi biliminin ortaya çıktığı ilk dönemlerde bireyin yaşadığı dinî tecrübeler bu alanın ana konusunu oluşturmaktaydı. Ancak modern bilimsel paradigmanın psikoloji bilimi üzerindeki etkisi arttıkça bireyin yaşadığı dinî tecrübeler ile ilgili çalışmalarda bir azalma gözlenmiştir. İnanan bireyin sübjektif bakış açısına dayanan bu çalışmalar, yöntemsel açıdan uygun olmadıkları gerekçesi ile yerini daha objektif verilerin kullanıldığı ampirik çalışmalara bırakmıştır.

Din psikologları, tasavvuf psikolojisinin alanına giren konularda ilk dönemlerden beri çalışmalar yapmaktadırlar. Ancak tasavvuf psikolojisinin sınırlarının belirlenmesi ve tanımının yapılması konusunda çok az çalışma vardır. Bu araştırmanın temel amaçlarından biri tasavvuf psikolojisi alanının sınırlarını belirlemeye çalışmak ve bu sınırları göz önünde bulundurarak tasavvuf psikolojisinin yeni bir tanımını yapmaktır. Çalışmanın bir diğer amacı da din psikolojisi açısından merkezi bir konumda bulunan dindarlı̆̆ın tecrübî boyutunun tasavvuf psikolojisi alanı ile olan ilişkisini belirginleştirmeye çalışmaktır. Bu amaçla dindarlığın tecrübi boyutu, dinî tecrübe, mistik tecrübe, tasavvufî tecrübe ve tasavvuf psikolojisi kavramları karşılaştırmalı olarak irdelenmiştir.

Bireyin dinî hayatını, bütün genişliği ve derinliği ile anlamaya ve açılamaya çalışmak din psikoloğunun en temel görevi olarak kabul edilmektedir. ${ }^{1}$ Dinî hayatın derinliğine anlaşılabilmesi ise yaşanan dinî tecrübelerin, birey için ne anlam ifade ettiğini bilmeye bağlıdır. Bu bağlamda, din psikolojisinin temel çalışma alanı da dini hayatın birey tarafından deneyimlenen sübjektif yönü olarak karşımızda durmaktadır. ${ }^{2}$ Ancak;

Faruk Karaca, Din Psikolojisi, İlaveli 2. bs. (Trabzon: Eser Ofset Matbaacılık, 2015), 11.

Hüseyin Certel, Din Psikolojisi (Isparta: Tuğra Ofset, 2011), 25. 
günümüzde din psikolojisi alanında yapılan akademik çalışmaların daha çok dinî hayatın yüzeysel tezahürlerini konu edindiği görülmektedir. Dinî hayatın derinliğine anlaşılması, yoğun dinî tecrübelerin bireysel düzlemde incelenmesi ile mümkün olabilmektedir. Bu durum, tasavvufî hayatın ve doğal olarak tasavvuf psikolojisinin din psikolojisi için sunduğu verilerin önemini göstermesi açısından önemlidir. Bu bakış açısı, tasavvuf psikolojisinin, din psikolojisi bilimi içerisindeki konumunun tartışılmasını gerekli kılmaktadır.

Din psikoloğu açısından önemli olan, dinî tecrübenin ifade ediliş şekilleri hakkında felsefî veya teolojik bir fikir edinmek değil; dinî tecrübeyi yaşayan kişiler için bunun ne anlam ifade ettiğini ve dinî tecrübenin onların dinî hayatlarını nasıl etkilediğini belirlemeye çalışmaktır. ${ }^{3}$ Ana akım psikolojinin alt alanı olarak kabul edilen din psikolojisi, bir felsefî akım veya teolojik bir alan olarak değil; psikolojinin bir alt alanı olarak bireylerin yaşadıkları tecrübeleri ve bu tecrübelerin onların hayatlarına yansımalarını konu edinmektedir. ${ }^{4}$

\section{Dindarlığın Tecrübî Boyutu ve Dinî Tecrübe}

Dünya dinleri arasında, dindarlığın inanan bireyin hayatından nasıl tezahür ettiği ile ilgili genel bir uzlaşma bulunmaktadır. Bu uzlaşma, dindarlığın kendini gösterdiği boyutlar için de geçerlidir. Dindarlığın dinî tecrübe boyutu, ibadet boyutu, inanç boyutu, bilgi boyutu ve etkileme boyutu hemen tüm dinler tarafından kabul edilmektedir. Bireysel dindarlığın işareti olarak kabul edilen ve ilk dönem din psikologları tarafından yoğun bir şekilde araştırılan tecrübi boyut, din psikolojisi disiplininin çalışma alanına girmektedir. $^{5}$

Bütün dinlerin bazı konularda müntesiplerine yönelik belli teşvikleri vardır ve onlardan bazı beklentileri doğrultusunda hareket ederek dinî duygular hissetmelerini beklerler. İşte bu gibi durumlar, dindarlı̆̆ın tecrübi (duygusal) boyutunu ifade eder. ${ }^{6}$ Bireyin yaşadığı dinî tecrübenin türü ve tonu onu yaşayan bireye ve müntesibi bulunduğu dine göre değişiklik göstermektedir. Ancak din psikolojisi alanı açısından önemli olan, bireyin sübjektif algısı ve tecrübeye yüklediği anlamdır.

Veysel Uysal, “Dinî Tecrübe ve Din Psikolojisindeki Yeri”, İslamî Sosyal Bilimler Dergisi, $3 / 4$ (1995): 72. APA (American Psychological Association/ Amerikan Psikologlar Derneği) bünyesinde 1976 yılında 36. Bölüm olarak Din ve Maneviyat Psikolojisi Bölümü kurulmuştur. Ayrıntılı bilgi için Mary E. Reuder tarafından kaleme alınan A History of Division 36 (Psychology of Religion) isimli çalışmaya bakılabilir.

Charles Y. Glock, "Dindarlığın Boyutları Üzerine”, çev. M. Emin Köktaş, Din Sosyolojisi, ed. Yasin Aktay ve M. Emin Köktaş, (Ankara: Vadi Yayınları, 2007), 252.

6 Faruk Karaca, Din Psikolojisi, 1. bs. (Trabzon: Eser Ofset Matbaacılık, 2011), 104. 
Din psikolojisinin tarih sahnesine çıkmaya başladığı ilk dönemlerde, din psikolojisi biliminin öncüleri tarafından dinin tecrübi boyutuyla ilgili yapılan çalışmalar ümit vericidir. Ancak bu öncü araştırmalar takip edilmemiş ve ilerleyen dönemlerde dinî tecrübeyi konu alan çalışmalar oldukça azalmıştır. ${ }^{7}$ Bu durum, modern din psikolojisi bilimine hâkim olan bilimsel paradigmadan kaynaklanmaktadır. Dinin tecrübî boyutuyla ilgili çalışmalar, iç gözlem gibi oldukça sübjektif teknikler kullanmayı gerektirmektedir. Ancak objektif yöntemlerin kullanılmasını gerektiren hâkim paradigmanın yöntem anlayışı ile bu durum çelişmektedir.

Din psikolojisinin dini tecrübeye ve başka bir deyişle dindarlığın tecrübi boyutuna bakışı daha çok dini tecrübeyi yaşayanların veya buna tanık olanların beyanlarının değerlendirilmesi esasına dayanmaktadır. Bu değerlendirme daha çok öznel ve psikolojik bir gerçeklik olan tecrübenin, nesnel gerçekliğe uygun bir şekilde ifade edilmesi yoluyla sağlanmaktadır. ${ }^{8}$

Dinî, mistik ve transpersonel tecrübe kavramlarının birbiriyle ilişkisi ve ortak yönleri de din psikologlarının dikkatini çekmektedir. Bu bağlamda Horozcu tarafından bir çalışma kaleme alınmıştır. Araştırmacı öncelikle tecrübe

212 kavramının din psikolojisi literatüründeki terim anlamını açıklamakta ve tecrübenin sıra dışı yaşantıları ve olağan halleri ifade etmek için kullanıldığını belirtmektedir. ${ }^{9}$ Ancak dinî tecrübenin olağan durumlarda da yaşanabileceği göz önünde bulundurulmalıdır. Nitekim yoğun mistik tecrübeler de normal mistik tecrübeler de din psikolojisinin çalışma alanın içeresindedir. ${ }^{10}$ Araştırmacı ardından dini, mistik ve transpersonel tecrübe çeşitlerini ayrıntılı bir şeklîde sunmakta ve özellikle mistik tecrübe yaşama yollarını açıllamaktadır. ${ }^{11}$

Dinî tecrübe öznel bir nitelik taşımaktadır ve buna bağlı olarak da dışardan gözlem ile tespit edilmesi ve araştırılması mümkün değildir. $\mathrm{Bu}$ durumda, din psikologlarının önünde iki seçenek bulunmaktadır. Bunlardan ilki; dinî tecrübenin pozitif bilimler ışı̆̆ında çalışılmasının imkânsızlı̆̆ının kabul edilmesi ve bu alanın çalışma sahasının dışında tutulmasıdır. Ancak din psikolojisi bilimi açısında merkezi bir konumda bulunan dini tecrübenin, yöntemsel sorunlar nedeniyle din psikolojisinin çalışma alanının dışında

\footnotetext{
Karaca, Din Psikolojisi, 105.

Uysal, "Dinî Tecrübe ve Din Psikolojisindeki Yeri”, 87.

Ümit Horozcu, Din Psikolojisi Ders Kitabl, 1. bs. (İstanbul: Rağbet Yayınları, 2015), 183.

10 M. Mustafa Çakmaklığlu, "Yoğun Tasavvufî Tecrübelere ilişkin Söylemin İmkânı ve İşlevselliği",

Dinbilimleri Akademik Araştırma Dergisi, 14/1 (2014): 95.

11 Horozcu, Din Psikolojisi Ders Kitabı, 189.
} 
tutulması pek uygun görünmemektedir. ${ }^{12} \mathrm{Bu}$ da din psikologlarını ikinci seçeneğe yöneltmektedir: Dinî tecrübe yaşayan bireylerin öznel yaşantılarını nesnel yöntemler kullanarak analiz etmek. Bu noktada nitel araştırma yöntemleri ve nitel yöntemler içerisindeki tekniklerin kullanılmasının zarureti ortaya çıkmaktadır. Din psikologları derinlemesine mülakat başta olmak üzere pek çok nitel veri toplama tekniği kullanarak dinî tecrübeyi araştırma imkânına sahiptir.

\section{Tasavvuf, Tasavvuf Psikolojisi ve Tasavvufî Tecrübe}

Tasavvuf ve mistisizm arasındaki ilişkiye dair çok sayıda çalışma bulunmaktadır. Mistisizm, tüm dinlerin içe dönük boyutu; tasavvuf da İslam'ın mistik ve içe dönük veçhesi olarak ele alınmaktadır. ${ }^{13}$ Mistisizm, aynı zamanda 'insanın görünen nesnelerin ardındaki gerçeklik, sonsuzluk ve birliğe ulaşma yönündeki ruhi tecrübesi ve bu tecrübeyi ifade eden doktrin' olarak da tanımlanmaktadır. ${ }^{14}$

Bazı araştırmacılar tasavvufun, dinî bir mistisizm ve İslam kültüründe vücut bulmuş bir İslam mistisizmi olduğunu kabul etmektedirler. ${ }^{15}$ Bazı araştırmacılara göre ise tasavvuf mistisizminden tamamen farklıdır. ${ }^{16}$ Pazarlı'nın da belirttiği gibi mistisizm, insanın mantık ve muhakeme ile ulaşamadığı aşkın hakikatleri kalp ve sezgi yoluyla bulmaya çalışmasıdır. Bu genel yaklaşım göz önünde bulundurulduğunda tasavvuf ile mistisizmin aynı şey olmadığı söylenebilir. 'Kelimelerin kökenleri de tarih içerisindeki kullanımları da bu iki kavramın farklılığını ortaya koymaktadır. Tasavvuf kelimesinin sufizm şeklindeki çevirisi daha doğru bir kullanımdır' ${ }^{17}$

Mistisizm ile tasavvuf arasındaki ilişki, tasavvufun mistisizmin bir türü olup olmadığı ve tasavvuf ile mistisizmin karşılaştırması çok sayıda araştırmada tartışılmıştır. Ancak bu tartışma, din psikolojisinin ve bu çalışmanın kapsamı dışındadır. Bu çalışmada tasavvuf terimi, İslam dini içerisinde anlaşıldığı şekliyle sınırlandırılarak kullanılmıştır.

Tasavvuf, günlük hayatın içerisinde çeşitli alanlara hitap etmektedir. Bununla birlikte tasavvuf, bireye haz veren bir yol olarak da görülmektedir. Bu

Uysal, “Dinî Tecrübe ve Din Psikolojisindeki Yeri”, 71.

A. Reza Arasteh, Enis A. Sheikh, "Tasavvuf: Evrensel Benliğe Giden Yol”, Sufi Psikolojisi: Bilgeliğin Ruhu,

Ruhun Bilgeliği, haz. Kemal Sayar, (İstanbul: Timaş Yayınları, 2015), 54-55.

14 Muhammed Kızılgeçit, Din Psikolojisinin 200'ü, 1. bs. (Ankara: Otto Yayınları, 2017), 60.

5 Hayati Hökelekli, Din Psikolojisi, 10. bs. (Ankara: Türkiye Diyanet Vakfı Yayınları, 2013), 315.

16 Ahmet Yaşar Zengin, "Tasavvuf ve Mistisizm", İslami Araştırmalar Dergisi, 12/3-4 (1999): 368.

17 Osman Pazarlı, Din Psikolojisi, (İstanbul: Remzi Kitabevi), 158. 
yönüyle tasavvuf, birçok birey için büyük bir öneme sahiptir ve bu önem sadece bireyler için değil; küçük gruplar ve bazı kültürel topluluklar için de geçerlidir. ${ }^{18}$ Tasavvufi hayat, psişik süreçlerin toplamından oluşmaktadır ve dindarlığın ruhsal ve manevi yansıma ve görünümlerinin açıkça görüldüğü bir alandır. ${ }^{19}$ Tasavvufun bu yönü onu, din psikolojisinin doğal konusu haline getirmektedir. Din psikologları tasavvufa yönelişlerin motivasyonları başta olmak üzere birçok tasavvufi kavram ve durumları incelemişlerdir.

Oldukça derin yaşantı ve haller içeren tasavvufî hayatın din psikolojisi araştırmacıları tarafından farklı yöntem ve tekniklerle incelenmesi gerekmektedir. Ülkemizin tasavvufî gelenekler açısından oldukça çeşitli bir yapıya sahip olduğu ve tasavvufî bir yaşantıyı benimseyen bireylerin oldukça fazla olduğu göz önünde bulundurulduğunda bu alanın din psikolojisinin temel alanlarından biri olabileceği söylenebilir. Kaldı ki dünya genelinde de mistik ve dini tecrübeye olan ilgi ve buna bağlı olarak bu konuyla ilgili akademik çalışmalar hızla artmaktadır.

Tasavvufî hayatın psikolojik yönlerinin incelenmesi oldukça geniş bir alanı kapsamaktadır. Ancak ülkemizde bu alanla ilgili oldukça az sayıda çalışma bulunmaktadır. Özellikle din psikolojisi alanında, tasavvuf psikolojisi ve tasavvufi yaşantı ve genel olarak mistik tecrübe ile ilgili çok az sayıda ampirik çalışma bulunmaktadır. ${ }^{20}$ Din psikolojisinin ülkemizde gittikçe büyüyen ve ilgi gören bir alan olduğu göz önünde bulundurulduğunda tasavvuf psikolojisi ile ilgili çok sayıda ampirik çalışmanın yanı sıra farklı yöntem ve teknikler kullanılarak yapılan araştırmaların da olması beklenmektedir. ${ }^{21}$

Alanın tam olarak tanımlanamamış olması da tasavvuf psikolojisi çalışmalarının sınırlı olmasını etkilemektedir. Tasavvuf psikolojisi, kavramsal olarak da din psikologları arasında tam olarak kesin bir kullanım kazanamamıştır. Örneğin Merter; tasavvuf psikolojisine oldukça benzer anlamlar yüklediği 'Hal Psikolojisi' kavramını kullanmayı tercih etmektedir. Hal psikolojisi kavramı, tasavvufî yaşamda ön plana çıkan tecrübeleri ifade

18 Hasan Kayıklık, Din Psikolojisi: Bireysel Dindarlık Üzerine,2. bs. (Adana: Karahan Kitabevi, 2014), 235.

19 Hayrani Altıntaş, "Din Psikolojisi ve Tasavvuf”, Ankara Üniversitesi İlahiyat Fakültesi İslam İlimleri Enstitüsü Dergisi, 4, (1980): 171.

20 Bu çalışmalara Mehmet Süheyl Ünal tarafından gerçekleştirilen Mistik Tecrübe Ölçeğinin geçerlilik ve güvenirlik çalışmaları ile Mustafa Ulu tarafından üniversite öğrencileri ile gerçekleştirilen ve mistik tecrübe ile kişilik ilişkisini konu edinen çalışma örnek olarak gösterilebilir.

21 Tasavvuf psikolojisi ile ilgili konular; özellikle nitel ve karma yöntemler kullanılarak ve sadece kesitsel değil; boylamsal çalışmalar tasarlanarak sürdürülürse daha doğru ve derinlemesine verilere ulaşılabilir. 
etmek için kullanılmaktadır. ${ }^{22}$ Bu kavram, tasavvuf psikolojisi ile dindarlığın tecrübi boyutunun ortak yönünü ifade eden bir kavramdır.

İnanan bireyi tasavvufa yönelten motivasyonlar, din psikolojisinin çalışma alanı içerisindedir. Tasavvufî yaşama yönelmede etkili olan motivasyonların neler oldukları ve bunların hangi psikolojik kuramlar ışığında incelenmesi gerektiği hem kuramsal çalışmalar ile hem de alan araştırmaları ile çalışılmalıdır. Bu bağlamda Cengil tarafından yapılan çalışmada tasavvufa yönelişi açıklayan psikolojik kuramlar sıralanmış, ardından ilk dönem din psikologlarının tasavvufa yönelişi nasıl açıkladıkları özetlenmiştir. Araştırmacı aynı zamanda Türk din psikologlarının konuya bakışlarını da özetlemektedir. Ancak araştırmacı, çok fazla sayıda kuramın tasavvufa yönelmeyi nasıl açıkladıklarını sunduğu için ayrıntılı bir tartışma yapamamıştır. Fromm, Frankl, Kohlberg, Leuba ve James'in bu konudaki fikirleri genel hatlariyla verilmiştir. ${ }^{23}$ Burada sözü edilen kuramcıların tasavvufa yönelişi nasıl açıkladıkları ayrıntılı olarak çalışılıp bu kuramlar ışığında ampirik veriler toplanarak analizler yapılabilir.

Din psikolojisi disiplini içerisinde tasavvufa yönelmeyi etkileyen faktörler konusunda da oldukça sınırlı sayıda çalışma bulunmaktadır. Certel, tasavvufa yönelmeyi etkileyen psiko-sosyal faktörleri yedi başlıkta incelemektedir. Bunlar; daha ileri seviyede ve tatmin edici bir dini yaşantıya duyulan arzu, dinî suçluluk ve günahkarlık duygusu, dost, arkadaş ve aile bireylerinin etkisi, tasavvufun dini kurtuluş için daha emin bir yol olduğu düşüncesi, bir mürşidin himmetine duyulan ihtiyaç, kötü ve günah sayılan alışkanlıkları terk etme isteği ve diğer (rüya, tasavvuf erbabının davranışları vb.) faktörlerdir. ${ }^{24}$

Tasavvuf psikolojisi ile ilgili yayın yapan din psikologlarından biri de Hayrani Altıntaş'tır. Altıntaş tasavvuf psikolojisi ile ilgili geniş bir makale kaleme almıştır. Psikoloji, din psikolojisi, dini ve mistik tecrübe gibi kavramları açıklayarak bu alandaki temel kavramalara bütüncül bir şekilde değinmiş ve bu kavramların birbirleriyle ilişkilerini de açıklamaya çalışmıştır. Bu anlamda, dini tecrübe ile tasavvuf psikolojisinin açık bir şekilde ilişkili olduğunu göstermiştir. Yazar, bahsi geçen makaleyi yazma amaçlarını şu şekilde sıralamaktadır: mistik tecrübelerin, psikolojik açıdan hangi yönleriyle incelenebileceğini göstermek,

\footnotetext{
22 Mustafa Merter, “Hal Psikolojisi”, Maneviyat Psikolojisi II, ed. Mustafa Atak, (İstanbul: Elit Kültür Yayınları, 2017), 25.

23 Muammer Cengil, "Tasavvuf ve Tarikatlara Yöneliş Psikolojisi”, İslam Düşünce ve Geleneğinde Kutsiyet, Velayet, Keramet, 2017, ed. Yusuf Şevki Yavuz, KURAMER, 173.

24 Certel, Din Psikolojisi, 236-237.
} 
psikologların mistik fenomenleri nasıl incelediklerini ve tasavvufun hangi açılardan incelenebileceğini göstermeye çalışmak. ${ }^{25}$

\section{Tasavvuf Psikolojisinin Dindarlığın Tecrübî Boyutu ile İlişkisi}

Dindarlığın tecrübî boyutunu ilgilendiren tasavvufî yaşantının incelenmesi, din psikolojisinin temel araştırma alanlarından biridir. Tasavvuf, inanılan değerleri en derinden hissederek yaşamayı, diğer bir ifadeyle imanın bireysel yaşamda canlanmasını ve dindarlığın duygusal boyutunun ortaya çıkmasını sağlayarak din psikolojisinin sahasına kendiliğinden girmektedir. Nitekim din psikolojisi, dinin bireysel yaşamda beliren izdüşümlerini inceleyen bir bilim dalıdır. ${ }^{26}$

Tasavvuf, İslam dininin ortaya koyduğu kuralların, belirli yöntemler izlenerek, içsel ve derunî tecrübelerle idrak edilmesi ve yaşanması yoluyla, kişinin hakikate ulaşmasını sağlayan bir yaşam tarzıdır. Tasavvufî yaşayışta duygusal süreçler hâkimdir. Bu yüzden, tasavvuf yoluna giren ve orada ilerleyen insanın yaşadığı kişisel tecrübelerin ve bu tecrübelere bağlı değişim ve gelişimlerin din psikolojisi disiplini içerisinde incelenmesi büyük önem arz etmektedir. Bu yolla, tasavvufî tecrübeyi anlamak, bir bakıma İslam'ın mistik özünü ve dindarlığın tecrübî boyutunu anlamak anlamına da gelmektedir. ${ }^{27}$

Dindarlığın ana boyutlarından biri olan tecrübî (duygusal) boyut, din psikologları tarafından göz ardı edilemeyecek kadar önemli bir alandır. Tasavvufî yaşantı ve davranışların, kişinin dinî hayatı hakkında derinlikli çözümleme ve analizler yapma imkânı sunabileceği göz önüne alındığında, tasavvuf psikolojisinin, dindarlığın tecrübi boyutunun bir yansıması olarak ele alınmasının daha doğru olacağı söylenebilir. Ancak ülkemizde tasavvuf psikoloji ile ilgili yapılan çalışmaların büyük bir kısmı, din psikolojisi kitaplarındaki tasavvuf psikolojisi bölümlerinden oluşmaktadır. Bu kısa bölümlerde sıklıkla tasavvufî kavramlar işlenmekte ve tasavvufi gelişim evreleri aktarılmaktadir.

Dindarlığın tecrübî boyutunu çalışmanın zorluğu din psikologları tarafından kabul edilen bir husustur. Nitekim dinî tecrübenin dışavurum problemi, zaman zaman din psikologları tarafından tartışılmıştır. ${ }^{28}$ Tasavvufî

\footnotetext{
Altıntaş, "Din Psikolojisi ve Tasavvuf”, 171.

6 Hasan Kayıklık, Tasavouf Psikolojisi, 2. bs. (Ankara: Akçă̆ Yayınları, 2011), 40.

27 A. Şule Yüksel, M. Doğan Karacoşkun, "Tasavvuf Psikolojisi", Din Psikolojisi El Kitabı, ed. M. Doğan Karacoşkun, (Ankara: Grafiker Yayınları, 2012), 216.

28 Ahmet Albayrak, "Dinî Tecrübenin Dışa Vurum Problemi", Milel ve Nihal İnanç, Kültür ve Mitoloji Araştırmaları Dergisi, 2/2 (2005): 74
} 
tecrübenin bir dinî tecrübe çeşidi olduğu göz önünde bulundurulduğunda, tasavvufi bir yaşam tarzını benimseyen bireylerin hayatlarının ve yaşadıkları tecrübelerin din psikologları için değerli veriler sunacağı aşikardır.

Dinî inanç ve davranışların içselleştirilerek bireyin benliğine yerleşmesi ve sinmesi ve bu şekilde inanan bireyin hayatını etkilemesi zorlu bir süreçtir. Tasavvufî yaşantı bu süreçte tercih edilen yollardan birini oluşturmaktadır. Bu anlamda tasavvuf, İslam'ın içselleştirilmesi ve özümsenerek yaşanmasının yollarından biridir ki buna derunî dindarlık da denebilir. İslam'ın bir yaşanış biçimi olan tasavvufî yaşayış, derunî bireysel dindarlık olarak adlandırılmaktadır. ${ }^{29}$

Dini tecrübe yaşayanların ortak tasvirlerine ve anlatımlarına bakıldığında, dini tecrübenin mahiyetinin ortak noktalarının bulunduğu görülmektedir. Bunlardan en önemlileri dinî tecrübenin doğrudan bir kavrayış ve vasıtasız bir sezgi içermesidir. ${ }^{30}$ Bir 'Hâl' olarak da isimlendirilebilecek olan bu ortak noktalar, din psikolojisinin çalışma alanı içerisindeki öznel yaşantıyı içermektedir. Tasavvufi bir yaşantıyı benimseyen dindarların bu tür öznel hâlleri sıkça yaşadıkları düşünüldüğünde dinî tecrübe ile tasavvufî yaşantının ortak noktası belirginleşmektedir. İslam literatüründe 'Hâl İlmi' olarak bilinen tasavvuf, dindarlığın duygu odaklı bir yaşantı biçimi olarak yorumlanıp dindarlığın tecrübi boyutu içerisinde değerlendirilebilir.

Tasavvufi ve mistik tecrübe, dini tecrübenin bir türü olarak kabul edilir. ${ }^{31}$ Tasavvufî yaşantı ve davranışlar, inanan bireyin dinî hayatı hakkında derinlikli çözümlemeler yapma imkânı sunması bakımından din psikolojisi bilimi açısından önemlidir. Ancak tasavvufî yaşantıyı tercih edenlerin psikolojik durumlarını ve yaşadıkları tecrübeleri sadece ampirik araştırmalar yaparak yeterince anlamanın mümkün olmadığı bir gerçektir. Din psikolojisi alanında çalışan bilim insanlarının, bu yaşantı içindeki insanları daha iyi anlayabilmek için, daha farklı araştırma ve inceleme çalışmaları yapmaları bir ihtiyaç olarak ortadadır. Bu açıdan, katı materyalist anlayışın indirgemeci yaklaşımıyla şekillenmiş bir bilimsellikten öte, gerçeğin maddeye indirgenemeyeceğini söyleyen yeni bilimsel paradigmaya göre hareket edilerek, belirli iç gözlem biçimlerinin bilimsel yöntem olarak sayılabileceği fikri değerlendirilmektedir. ${ }^{32}$ 
Tasavvufî yaşam içerisinde insan, deruni yaşantısının pratik yansımaları olarak dinî tecrübe yaşar. Dinî tecrübe; tabiatüstü varlığın algılanması, onunla ilişkiye geçilmesi ve onun bilgisine götürecek şeylerin tecrübe edilmesi şeklinde tanımlanır. Dinî tecrübeyi, 'dinî hayat', 'dinî yaşantı' şeklinde ifade edenler olsa da o, dinî hayattan daha özel bir anlamı içeren 'yoğun bir psikolojik hal'i ifade etmektedir. Bu bakımdan dinî tecrübe, 'aşkın varlı̆̆ın delil, alamet, işaret ve tezahürlerini sezgisel olarak algılama, vasıtasız kavrama, kutsal ve ilahi olan ile içten ve duygusal bir biçimde ilişki kurma' şeklinde tarif edilmektedir. ${ }^{33}$

Tasavvuf, bir fikir sistemi ve bir yaşam tarzı olmasının yanında tecrübe edilen haller ve yaşantıları da içermektedir. ${ }^{34}$ Tasavvufun, zihinsel süreçlerden çok duygusal süreçlerin hâkim olduğu bir sistem olması, tasavvuf psikolojisinin odak noktasına inanan bireyin dinî ve mistik tecrübelerini ve bu tecrübelerin duygusal yansımalarını almasını gerektirmektedir. ${ }^{35}$ Nitekim mistik tecrübenin odak noktasında bireyin iç dünyası vardır ve bu süreçte birey, duygusal olarak aktiftir.

Din psikolojisi bilimi, tasavvufi yaşantı içerisinde ortaya çıkan dinî tecrübeleri araştırma konusu olarak ele almaktadır. Fakat din psikolojisinin, mistik yaşantıların tüm derinliklerine inebilmesi yer yer mümkün olamamaktadır. Çünkü bilimsel olmanın gerektirdiği yöntem ve teknikler dişında araştırma yapmak söz konusu değildir. Ancak, din psikolojisi, tasavvufî yaşantıyı, aktarılan tecrübeler bağlamında anlama çabasından geri durmamaktadır. Çünkü bu tecrübe, dinî hayatın içinde göz ardı edilemeyecek kadar önemli bir yere sahiptir. ${ }^{36}$

Tasavvuf, bir taraftan kültürel ve toplumsal özellikler taşırken diğer taraftan bireysel ve derunî hususiyet arz etmektedir. İşe tasavvufî hayatta ortaya çıkan bu bireysel derunî tecrübeler, başlı başına bir psikoloji olarak değerlendirilebileceği gibi din psikolojisi için de kaçınılmaz bir araştırma konusudur. Hâl böyle olunca tasavvufî tecrübeyi anlamak, bir bakıma İslam'ın mistik özünü anlamak olarak yorumlanabilir. ${ }^{37}$ Tasavvufî bir hayatı benimseyen kişilerin dinî tecrübeyi alışılmışın dışında ve yoğun bir tarzda yaşamaları, bu kişilerin ve yaşantılarının din psikolojisinin alanına girmesinin temel nedenlerinden biridir. ${ }^{38}$

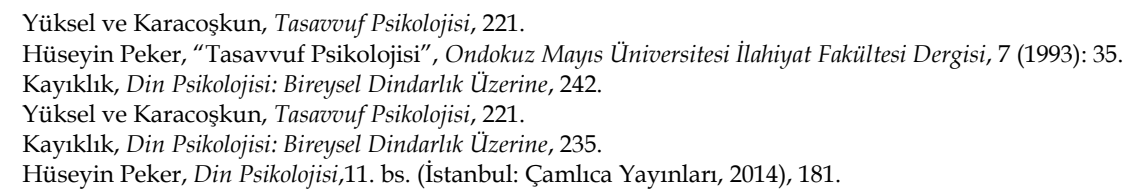




\section{Tasavvuf Psikolojisinin Mevcut Durumu ve Yeni Bir Tanım İhtiyac1}

Tasavvufi yaşantı, din psikolojisinin önemli araştırma alanlarından biridir. Çünkü o, inanılan değerleri en derinden yaşamayı yani imanın bireysel hayatta tezahür etmesini ifade eder. Bilindiği gibi din psikolojisi de dinin bireysel yaşamdaki yansımalarını, kendine has yöntemlerle inceleyen bir bilim dalıdır. ${ }^{39}$ Ancak ülkemizde önemli bir yere sahip olan tasavvufî yaşantının din psikolojisi bağlamında incelendiği çalışma sayısı oldukça sınırlıdır. Tasavvuf psikolojisi olarak isimlendirilen bu alanla ilgili ülkemizde yapılan çalışmaların oldukça yüzeysel ve yetersiz olduğu söylenebilir.

Tasavvuf psikolojisi, 'İslam'ın deruni formu olan tasavvufi yaşantıyı psikolojik açıdan inceleyen spesifik bir alandır'. ${ }^{40} \mathrm{Bu}$ alanın sınırlarının belirlenmesi, tasavvufî hayatın hangi yönleri ile inceleneceği, birey ve grup düzlemindeki araştırmaların hangi yöntem ve teknikler kullanılarak yapılacağı, bu disiplinin çalışma alanı içerisinde hangi bireylerin bulunması gerektiği gibi birçok sorunun cevabı, bu alanın olgunlaşarak bağımsızlaşmasına katkı sağlayacaktır.

Tasavvufun psikolojik açıdan sağaltım amaçlı kullanılabileceğine ilişkin görüşler ilk dönemlerden beri dile getirilmektedir. ${ }^{41}$ Nitekim tasavvuf içerisindeki kimi dinamikler ve spesifik uygulamalar, psikoterapötik süreç içerisinde iyileştirici ve rehabilite edici olarak halihazırda kullanılmaktadır. 'Sufi Ruhbilimi' kavramı, tasavvufi uygulamaların zihinsel açıdan sorun yaşayan kişilerde kullanılabileceği iddiasına dayanmaktadır. ${ }^{42}$ Din psikolojisinin bir çalışma alanı olan manevi danışmanlık ve rehberlik hizmetlerinde bile tasavvufi uygulamaların kullanılması söz konusu iken din psikolojisi ana akımı içerisinde tasavvuf psikolojisinin tam anlamıyla tanımlanıp sınırlarının belirlenmemiş olduğu görülmekledir.

Nefs kavramı, nefsin psikolojik yapısı ve tabiatı din psikolojisi açısında şeyh-mürit ilişkisi ve bu ilişkinin psikolojik temelleri gibi konular din psikologları tarafından çalışılmaktadır. ${ }^{43}$ Ancak; din psikolojisinin temel görevi

\footnotetext{
Yüksel ve Karacoşkun, Tasavouf Psikolojisi, 218.

Kızılgeçit, Din Psikolojisinin 200'ü, 74.

Altıntaş, "Din Psikolojisi ve Tasavvuf", 183.

42 Ayrıntılı bilgi için Muhammed Ecmel' in Sufi Ruhbilimi ve Arthur J. Deikman'ın Tasavouf ve Psikiyatri isimli eserlerine bakılabilir.

43 Hayati Hökelekli, İslam Psikolojisi Yazıları, 2. bs. (İstanbul: Değerler Eğitimi Merkezi Yayınları, 2012), 43-60, 177-202.
} 
ve çalışma alanı bu kavramları tanımlamaktan ziyade sözü edilen süreç ve ilişkilerin bireyin dinî hayatına yansımalarını araştırmaktır.

Tasavvuf psikolojisi ile din psikolojisinin alanı tasavvuf değil; tasavvufi yaşantı olmalıdır. Ancak mevcut din psikolojisi kaynaklarında tasavvufî yaşantının değil tasavvufun temel kavramları verilmektedir. Tasavvuf psikoloji çalışmalarında tasavvufun temel kavramlarının zikredilmesi gayet normal ve gereklidir. Ancak; tasavvuf psikolojisi olarak adlandırılan alanın tasavvufun temel kavramlarından ve tasavvufi gelişim evreleri ile nefsin mertebelerinin açıklamasından çok daha fazlası olduğu da aşikârdır.

Ayten ve Düzgüner, tasavvuf psikolojisini ‘Sufiler için öngörülen nefsin arınması ve ahlaki olgunlaşmanın gerçekleştirilmesi süreçlerinin sufiler üzerindeki tesirlerinin psikolojinin verileri ile anlaşılması çabası' olarak tanımlamaktadırlar. ${ }^{44}$ Araştırmacılar bu tanımın, tasavvuf psikolojisinin dinin insan üzerindeki etkileriyle ilgilenen din psikolojisinin bir alt dalı olarak görülebileceğinin de bir göstergesi olduğunu belirtmektedirler. Tasavvuf psikolojisinin özgün bir tanımı olması ve tasavvuf psikolojisinin din psikolojisi ile ilişkisine değinmesi bakımından değerli olan bu tanım, sadece sufileri kapsaması ve nefsin arınması ile ahlaki olgunlaşmaya odaklanması bakımından eksik olarak değerlendirilebilir.

Ülkemizde, din psikologları tarafından kaleme alınan ve tasavvuf psikolojisi başlığı altında yapılan çalışmaların bir kısmı ise tasavvufu, bir gelişim modeli olarak görmektedir. Nitekim Kayıklık, tüm manevi geleneklerin psikolojik bir bakış açısına ihtiyaç duyduklarını ve bu bakış açısının, insan doğasının ve manevi gelişim sürecinin anlaşılması için vazgeçilmez bir unsur olduğunu belirtmektedir. ${ }^{45}$ Tasavvufu bir dinî gelişim modeli olarak değerlendiren diğer bazı araştırmacılar, tasavvufun bir manevi gelişim süreci olarak tanımlanabileceğini belirtmektedir. Buna bağlı olarak, bu yaklaşımın, tasavvuf psikolojisini dinî gelişim psikolojisinin bir alt başlığı olarak incelediği söylenebilir. Nitekim araştırmacı ilgili çalışmanın büyük bir kısmını tasavvufî gelişim evrelerini açıklamaya ayırmıştır. ${ }^{46}$

Din psikolojisi alanında çalışan araştırmacılardan bir kısmının tasavvuf psikolojisini dinî gelişim modelleri ile açıkladığı görülmektedir. Ancak; tasavvuf psikolojisini bir dinî gelişim modeli olarak incelenmesi, bazı yönlerden

\footnotetext{
44 Ali Ayten ve Sevde Düzgüner, Tasavvuf Psikolojisine Giriş: Bireysel Arınma ve Güzel Ahlak, 1. bs. (İstanbul: Sufi Kitap Yayınları, 2017), 44.

45 Kayıklık, Din Psikolojisi: Bireysel Dindarlık Üzerine, 235.

46 Karaca, Din Psikolojisi, 2. bs., 201.
} 
eleştirilebilir. Bu duruma getirilecek en temel eleştiri, bütün Müslümanların tasavvuf ehli olmadıkları ve bu yüzden de bu modelin tüm Müslümanlar için geçerli olamayacağıdır.

Tasavvufî yaşantı, küçük yaşlardaki kutsal bir yaratıcıya inanma ihtiyacının, ileriki yaşlarda dinî yaşayışta derunileşme isteğinin bir vasıtası olarak ortaya çıan bir eğilim olarak da görülmektedir. ${ }^{47}$ Tasavvufu, dinî bireyselleşmeye giden yol olarak tanımlamak da mümkündür. ${ }^{48}$ Bu bakış açısı, Kayıklık tarafından geliştirilen ve tasavvufi yaşantıyı açıklayan 'deruni bireysel dindarlık' bakış açısıyla da örtüşmektedir. Bu açıdan bakıldığı zaman tasavvufun öngörmüş olduğu dini gelişim modelinin bilişsel, sosyal ve duygusal açıdan belli bir yeterlilik düzeyine ulaşmış olan bireylerin dinî bilincinde meydana gelen değişime odaklandığı söylenebilir. Nitekim bu değişim, tasavvuf psikolojisinin temel çalışma alanlarından birini oluşturmaktadır. ${ }^{49}$

Tasavvufî yaşam, psikolojik yaşamın bir şekli olarak da değerlendirilmektedir. Yazar, bu bakış açısıyla paralel olarak da Maslow'un ihtiyaçlar hiyerarşisindeki evreler ile nefsin gelişim evrelerinin paralellik gösterdiğini iddia etmekte ve çalışmasında bu benzerlikleri ele almaktadır. ${ }^{50}$ Hilmi Ziya Ülken ise insan ruhunun geçirdiği mertebeleri, Gazali'den aktarmakta ve bu mertebelerin aynı zamanda tasavvufî mertebeler olarak da bilindiğini belirtmektedir. Bu mertebelerin her birinin psikolojik tahlilini yapan yazar, tasavvuf psikolojisinin bu mistik tecrübelerle ilgilendiğini ifade etmektedir. $^{51}$

Tasavvuf psikolojisi alanında çalışma yapan araştırmacıların bir kısmı tasavvuf ile psikolojiyi karşılaştırma yoluna giderek bu iki alanın ortak ve benzer yönlerini açıklamışlardır. Örneğin Ülken tasavvuf ile psikoloji arasındaki benzerliklere dikkat çekmektedir. Tasavvufta, ruhi hastalıklardan kurtulmak istendiğinde izlenen yol ile Pierre Janet'in psikoterapide izlediği yöntemin benzerliğini vurgulayan yazar; zühd, fena ve beka evrelerinin psikolojik iyileşme süreci ile ortak olan yönlerinden bahsetmektedir. ${ }^{52}$

\footnotetext{
47 Muammer Cengil, “Tasavvufi Yaşantıya Yönelmede Etkili Olan Psiko-Sosyal Nedenler”, Tasavvuf İlmîve Akademik araştırma Dergisi, 4/11 (2003): 215.

48 Arasteh ve Sheikh, "Tasavvuf: Evrensel Benliğe Giden Yol", 62.

49 Kayıklık, Din Psikolojisi: Bireysel Dindarlık Üzerine, 241.

50 Ali Kuşat, "Nefis Mertebelerine Psikolojik Bir Yaklaşım”, Tasavvuf İlmî ve Akademik Araştırma Dergisi, 3/9 (2002): 120

51 Hilmi Ziya Ülken, Tasavvuf Psikolojisi: 1944-1945 Üniversite Serbest Konferanslarından Ayrı Bası, (İstanbul Kenan Matbaasi, 1946).

52 Ülken, Tasavvuf Psikolojisi: 1944-1945 Üniversite Serbest Konferanslarından Ayrı Bası, 199.
} 
Görüldüğü gibi ülkemizde yapılan ilk dönem din psikolojisi çalışmalarında tasavvuf psikolojisinin temel konuları merak uyandırmış ve akademisyenler tarafından çalışılmıştır.

Din Psikolojisi ile tasavvuf ilişkisi de din psikologlarının ilgilendiği bir konudur. Din psikolojisi ve tasavvufu birer bilim dalı olarak nitelendiren ve psikoloji ile tasavvufu birçok yönden karşılaştıran çalışmalar bulunmaktadır. ${ }^{53}$ Din psikolojisi ile tasavvuf ilişkisine farklı bir bakış açısıyla yaklaşıp tasavvuf psikolojisi ile tasavvufun net bir şekilde ayrılmaması gerektiğini ve tasavvufun da bir psikoloji türü olarak değerlendirilebileceğini belirten akademisyenler de bulunmaktadır. ${ }^{54}$ Ancak bu bakış açısı, müstakil bir alan olması gereken tasavvuf psikolojisinin bu çabasını zorlaştırmaktadır.

Peker; tövbe, vecd, zühd ve zikir gibi tasavvufi yaşantı ve hâllerin psikolojik tahlilini yapmaktadır. Bunu yaparken hem İslami literatürden hem de Alman ekolü başta olmak üzere batı literatüründen faydalanmaktadır. ${ }^{55}$ Yazar, Din Psikolojisi isimli kitabında ise tasavvufî yaşantı başlı̆̆ı altında tasavvufî yaşantının psikolojik karakteristiklerini şu şekilde sıralamaktadır: bir şeye bağlanmak, teslim olmak, günahlardan arınmak, nefsin istek ve arzularını terk etmek, Allah dişındaki her şeyi gönülden çıkarmak ve zihni sadece Allah düşüncesi ile doldurmak. Bu aşamaların psikolojik analizini yapan yazar, tasavvufun bu aşamalar yoluyla Allah'la bir olma yolu olduğunu ifade etmektedir. $^{56}$

Tasavvufi yaşantı, deruni bireysel dindarlık olarak da nitelendirilmektedir. Bu dindarlık türü, insanın inandığı, bağlandığı, teslim olduğu ve benimsediği değerleri gönülden yaşaması olarak tanımlanmaktadır. $\mathrm{Bu}$ dindarlık türünde bireysellik ve öznel yaşantı ön plandadır. Bu da din psikolojisinin bu alanla ilgilenmesi gerektiğini göstermektedir. ${ }^{57}$

İnanan bireyi, tasavvufa ve tasavvufi yaşantıya yönlendiren çok sayıda faktör bulunmaktadır. Ancak bunlardan bireysel ve içsel olan nedenler din psikolojisinin çalışma alanı içerisindedir. Bireyi tasavvufî bir yaşama yönlendiren motivasyonların başında mevcut dindarlık anlayışlarının bireyi tatmin edememesi gelmektedir. İçsel bir tatmin yaşayıp dini deruni bir formda yaşamak isteyen bireyler, tasavvufa yönelebilmektedirler. Bireyi tasavvufa

\footnotetext{
Yüksel ve Karacoşkun, Tasavvuf Psikolojisi, 216-219.

4 Kayılık, Din Psikolojisi: Bireysel Dindarlık Üzerine, 274.

5 Peker, "Tasavvuf Psikolojisi, 35-52.

56 Peker, Din Psikolojisi, 183-197.

57 Kayıklık, Tasavouf Psikolojisi, 48.
} 
yönelten diğer faktörler de bu ana faktörün yansımaları şeklinde ortaya çıkmaktadır. Örneğin materyalist ve konformist bir yaşam tarzını anlamsız bulmak, kendi varlığının hikmetlerini anlamaya çalışmak ve ulvî bir güç ile doğrudan irtibatlı olmayı istemek bu yansımalardan bazılarıdır. ${ }^{58}$

Türkiye'de tasavvuf psikolojisi ile ilgili yazılan eserler çoğunlukla tasavvufu, tasavvufî gelişim evrelerini ve tasavvufun temel kavramlarını ele alıp özetlemektedirler. Ancak din psikolojisi bağlamında kaleme alınan eserlerin tasavvuftan ziyade kişinin tasavvufi yaşantısını ve bu yaşantıya götüren motivasyonlar ile tasavvufî yaşantının psikolojik çıktılarını ele almaları daha uygun olacaktır. Bunun yapılabilmesi için öncelikle tasavvuf psikolojisinin, tasavvuftan bağımsız tanımları yapılmalı ve tasavvuf psikolojisinin sınırları net bir şekilde çizilmelidir.

Psikoloji ve özelde din psikolojisi bağlamında düşünüldüğünde tasavvuf psikolojisi şu şekilde tanımlanabilir: “Tasavvuf psikolojisi, tasavvufi yaşantıyı benimseyen bireylerin; bu yaşam tarzını seçmedeki motivasyonların, yaşadıkları mistik tecrübeleri, tasavvufî hayatın ve mistik tecrübelerin bireyde meydana getirdiğ i değişimi

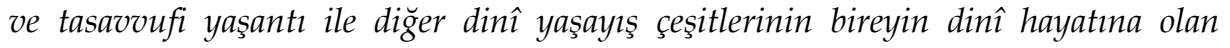
etkilerini din psikolojisi biliminin verileri doğrultusunda anlamaya ve açılamaya çalışan bir alandır".

Yaptığımız tanımda görüldüğü üzere tasavvuf psikolojisi alanı, tasavvufa yönelten motivasyonlara, tasavvufi hayatı benimseyenlerin yaşadıkları mistik tecrübelere, tasavvufi yaşamla birlikte ortaya çıkan değişime ve tasavvufi yaşamın dindarlığın genel formunu nasıl etkilediğine odaklanmalıdır. Bu sınırlar, din psikolojisi biliminin sınırları içerisinde olan konuları kapsamaktadır.

\section{Sonuç}

Tasavvufî yaşantı biçimi içerisinde görülen tasavvufi ve mistik deneyimler, birer dinî tecrübe çeşidi olarak değerlendirildiğinde, bu yaşantıların dindarlığın tecrübî boyutunun birer yansıması oldukları söylenebilir. Bu durum, din psikologları için oldukça önemli olan dindarlığın tecrübi boyutunun araştırılması için bir fırsat olarak değerlendirilmeli ve bu yaşantılar din psikologları tarafından ayrıntılı ve aynı zamanda sistematik bir şekilde analiz edilmelidir.

\footnotetext{
58 Kayılkık, Din Psikolojisi: Bireysel Dindarlı Üzerine, 252.
} 
Bireyin yaşadığı tecrübeler ve bu tecrübelerin onun dinî hayatına yansımaları, din psikolojisinin temel konularından birini oluşturmaktadır. Tasavvufî yaşantı ve dindarlığın tecrübi boyutu göz önüne alınarak; bireysel tecrübelerin ön planda olduğu ve duygusal yoğunluğun sıkça yaşandiğı tasavvufî yaşantının, dindarlığın tecrübi boyutu içerisinde incelenmesinin daha uygun olacağı söylenebilir.

Tasavvufi bir yönelime sahip olan inananlar ile çalışan uzmanların, tasavvufun temel kavram ve ilkelerinin yanında İslam dininin ana konularına da hâkim olmaları beklenir. Ancak günümüzde dindarlığın olmadığı bir maneviyatın tezahürü olarak ortaya çıkan sufilik ile ilgili bazı çalışmalar sanki İslam dinini ıskalamakta ve tasavvufu başlı başına bir sistem ve dünya görüşü olarak ele almaktadırlar. Bu durum, tasavvufî hayatın tam olarak anlaşılamaması sorununu doğurmaktadır. Buna çözüm olarak; bu alanın din psikolojisi gibi kendini ispatlamış bir alanın altında çalışılması önerilebilir.

İlk dönem din psikolojisi çalışmalarında görüldüğü üzere, dinî tecrübe ile ilgili araştırma ve çözümlemeler yapmak ancak 'iç gözlem' gibi sübjektif bazı tekniklerin kullanılması ile mümkün olmaktadır. Günümüzde de dinin tecrübî boyutu ve tasavvuf psikolojisi ile ilgili çalışma yapmak, inanan bireyin hassas duygularının incelenebilmesine bağlıdır. Ancak; bu duyguların anket ve ölçek gibi nicel tekniklerle incelenebilmesi pek mümkün değildir. Kişinin iç gözlemini aktarabilmesi için daha uygun nitel bir araştırma tekniği olan derinlemesine mülakat vb. teknikler kullanılarak bu zorluk aş1labilir.

Sonuç olarak bu çalışmada, tasavvuf psikolojisinin günümüzdeki durumu, dini-mistik ve tasavvufi tecrübe kavramları ve tasavvuf psikolojisi ile dindarlığın tecrübi boyutunun ilişkisi ortaya konulmuştur. Aynı zamanda tasavvuf psikolojisinin sınırları yeniden çizilerek din psikolojisi çalışmalarında kullanılmak üzere yeni bir tanımlama yapılmıştır.

\section{Kaynakça}

Albayrak, Ahmet. "Dinî Tecrübenin Dişa Vurum Problemi". Milel ve Nihal İnanç, Kültür ve Mitoloji Araştırmaları Dergisi, $2 / 2$ (2005): 65-79.

Altıntaş, Hayrani. "Din Psikolojisi ve Tasavvuf". Ankara Üniversitesi İslam İlimleri Enstitüsü Dergisi, 4 (1980): 171-197.

Apaydın, Halil. Din Psikolojisi Terimleri Sözlüğ̈̈. 1. bs., İstanbul: Bilimkent Yayınları, 2016. Arasteh, A. Reza ve Sheikh, Enis A. "Tasavvuf: Evrensel Benliğe Giden Yol". Sufi Psikolojisi: Bilgeliğin Ruhu, Ruhun Bilgeliği, haz. Kemal Sayar, 53-96. İstanbul: Timaş Yayınları, 2015.

Ayten, Ali ve Düzgüner, Sevde. Tasavouf Psikolojisine Giriş: Bireysel Arıma ve Güzel Ahlak. 1. bs., İstanbul: Sufi Kitap, 2017. 
Cengil, Muammer. "Tasavvufî Yaşantıya Yönelmede Etkili Olan Psiko-Sosyal Nedenler". Tasavouf İlmî ve Akademik Araştırma Dergisi, 4/11 (2003): 213-240.

Cengil, Muammer. "Tasavvuf ve Tarikatlara Yöneliş Psikolojisi”. İslam Düşünce ve Geleneğinde Kutsiyet, Velayet, Keramet, ed. Yusuf Şevki Yavuz, KURAMER, (İstanbul: 2017), 169-179.

Certel, Hüseyin. Din Psikolojisi. Isparta: Tuğra Ofset, 2011.

Çakmaklığlu, M. Mustafa. "Yoğun Tasavvufî Tecrübelere İlişkin Söylemin İmkânı ve İşlevselliği". Dinbilimleri Akademik Araştırma Dergisi, 14/1 (2014): 85-122.

Deikman, Arthur J. "Tasavvuf ve Psikiyatri". Sufi Psikolojisi: Bilgeliğin Ruhu, Ruhun Bilgeliği, haz. Kemal Sayar, 51-176. İstanbul: Timaş Yayınları, 2015.

Ecmel, Muhammed. "Sûfî Ruhbilimi". Sufi Psikolojisi: Bilgeliğin Ruhu, Ruhun Bilgeliği, haz. Kemal Sayar, 97-115. İstanbul: Timaş Yayınları, 2015.

Glock, Charles Y. "Dindarlığın Boyutları Üzerine”. Din Sosyolojisi, der. Yasin Aktay ve M. Emin Köktaş, 250-271. Ankara: Vadi Yayınları, 2007.

Horozcu, Ümit. Din Psikolojisi Ders Kitabı. İstanbul: Rağbet Yayınları, 2015.

Hökelekli, Hayati. İslam Psikolojisi Yazıları. 2. bs., İstanbul: Değerler Eğitimi Merkezi Yayınlar1, 2012.

Hökelekli, Hayati. Din Psikolojisi. 10. bs., Ankara: Türkiye Diyanet Vakfı Yayınları, 2013.

Karaca, Faruk. Din Psikolojisi. 1. bs., Trabzon: Eser Ofset Matbaacılık, 2011.

Karaca, Faruk. Din Psikolojisi. İlaveli 2. bs., Trabzon: Eser Ofset Matbaacılık, 2015.

Kayıklık, Hasan. Tasavouf Psikolojisi. Gözden Geçirilmiş 2. bs., Ankara: Akçağ Yayınları, 2011.

Kayıklık, Hasan. Din Psikolojisi: Bireysel Dindarlı Üzerine. 2. bs., Adana: Karahan Kitabevi, 2014.

Kızılgeçit, Muhammed. Din Psikolojisinin 200'ü. 1. bs., Ankara: Otto Yayınları, 2017.

Kuşat, Ali. "Nefis Mertebelerine Psikolojik Bir Yaklaşım”. Tasavvuf İlmî ve Akademik Araştırma Dergisi, 3/9 (2002): 119-128.

Merter, Mustafa. "Hal Psikolojisi". Maneviyat Psikolojisi II, ed. Mustafa Atak, 25-36. İstanbul: Elit Kültür Yayınları, 2017.

Pazarlı, Osman. Din Psikolojisi. İstanbul: Remzi Kitabevi, 1968.

Peker, Hüseyin. "Tasavvuf Psikolojisi". Ondokuz Mayıs Üniversitesi İlahiyat Fakültesi Dergisi, 7 (1993): 35-52.

Peker, Hüseyin. Din Psikolojisi. 11. bs., İstanbul: Çamlıca Yayınları, 2014.

Reuder, Mary E. "A History of Division 36 (Psychology of Religion)". Unification through Division: Histories of the divisions of the American Psychological Association, ed. Donald A. Dewsbury, 91-108. Washington DC: American Psychological Association, 1999.

Uysal, Veysel. "Dinî Tecrübe ve Din Psikolojisindeki Yeri”. İslamî Sosyal Bilimler Dergisi, 3/4 (1995): 69-87.

Ulu, Mustafa. “Mistik Tecrübe ve Kişilik İlişkisi Üzerine: Erciyes Üniversitesi İlahiyat Fakültesi Öğrencileri Örneklemi”. Cumhuriyet İlahiyat Dergisi, 22/1 (2018): 3361.

Uysal, Veysel. "Dinî Tecrübe ve Din Psikolojisindeki Yeri”. İslamî Sosyal Bilimler Dergisi, 3/4 (1995): 69-87.

Ülken, Hilmi Ziya. Tasavvuf Psikolojisi: 1944-1945 Üniversite Serbest Konferanslarından Ayrı Basım. İstanbul: Kenan Matbaası, 1946. 
Ünal, Mehmet Süheyl. "Mistik Tecrübe Ölçeği'nin Güvenilirlik ve Geçerlik Çalışması”. Dinî ve Mistik Tecrübe Yazıları, ed. Mehmet Süheyl Ünal, 101-164, Rize: STS Yayıncilik, 2012.

Yüksel, Ayşe Şule ve Karacoşkun, Mustafa Doğan. “Tasavvuf Psikolojisi”. Din Psikolojisi El Kitabı, ed. Mustafa Doğan Karacoşkun, 215-233, Ankara: Grafiker Yayınları, 2012.

Zengin, Ahmet Yaşar. "Tasavvuf ve Mistisizm”. İslamî Araştırmalar Dergisi, 12/3-4 (1999): 367-370. 
Doi: 10.34247/artukluakademi.609077

\section{Muhammet Cevat Acar \\ The Evaluation of Sufi Psychology within the Experiential Dimension of Religiosity and the Need for a New Definition}

Citation/@: Acar, Muhammet Cevat, The Evaluation of Sufi Psychology within the Experiential Dimension of Religiosity and the Need for a New Definition, Artuklu Akademi 2019/6 (2), 209-228.

\section{Extended Abstract}

In the early periods when psychology of religion emerged as a science, the focus of this field was to examine the religious experience of the individual. However, with the increase of the modern scientific paradigm on mainstream psychology, studies about religious experiences of the individual has been started to decrease. The studies on religious experiences have been replaced by empirical studies using more objective data on the grounds that religious experiences cannot be measured by empirical methodology and modern scientific paradigm as religious experience is based on the subjective point of view of the believing individual.

Similar to psychologists, the psychologists of religion have been conducting studies on subjects falling within the field of Sufi psychology since $20^{\text {th }}$ century. Although, these studies are conducted within the frame of Sufism, there are a few researches concentrating on determining and defining the boundaries of Sufi psychology. One of the main objectives of this research is to define the boundaries of the field of Sufi Psychology and to introduce a new definition for the Sufi Psychology by considering the defined boundaries. Another aim of this study is to clarify the relationship between the experiential dimensions of religiosity, which is central to the psychology of religion, with the psychology of Sufism. To achieve this goal, the experiential dimension of religiosity, religious experience, mystical experience and psychology of Sufism have been examined comparatively.

Researchers of religious psychology need to use different methods and techniques while examining Sufi lifestyle embodied by deep experience and various states of spiritual experience. As, Turkey includes many different Sufi traditions and individuals adopting Sufi lifestyle, it can be said that this area can be one of the fundamental fields for psychology of religion. Moreover, the growing interest in mystical and religious experience throughout the world correlatively affected the increase of academic studies on this subject.

As to the religious psychologists, the experiential dimension, which is one of the main dimensions of religiosity, is an area that should not be ignored by those working in this field. Considering that Sufi experiences and behaviours provide an opportunity for deep analysis of one's religious life, it can be said that it would be more appropriate to treat Sufi psychology as a reflection of the experiential dimension of religiousness. However, most of the studies on Sufi psychology in Turkey appear as individual chapters in books of religious psychology. In these short chapters, the key terms and concepts of Sufism and the historical development process of Sufism are explained. 
Furthermore, the focus of Sufi psychology and psychology of religion should not be directly Sufism, but the Sufi lifestyle. However, in the sources of psychology of religion, the basic concepts of Sufism are mostly given. Of course, it is necessary to give place to the main concepts of Sufism in the Sufi psychology studies. But, it should not be neglected that the Sufi psychology covers a broader research area than just the main concepts of Sufism or the explanation of the stages of Sufism.

Studies on Sufism psychology in Turkey mostly discuss and summarize the main concepts of developmental stages of Sufism. However, it would be more appropriate to consider the mystical life of the person rather than Sufism as a discipline, and the psychological outputs of the mystic life and the motivations leading one to this life. To do this, the definitions of Sufism psychology should be made independent from Sufism and the boundaries of Sufism psychology should be clearly drawn.

It is seen that some of the researchers working in the field of psychology of religion explain the psychology of Sufism through religious development models. The study of Sufi psychology as a model of religious development has some weak points; thus it is criticized in some ways. The main criticism to be voiced to this model is that not all Muslims are Sufis and therefore this model cannot be employed to all Muslims.

Considering the psychology and psychology of religion in particular, the psychology of Sufism can be defined as follows: "Psychology of Sufism is an area that tries to understand and explain the motivations in choosing this lifestyle, the mystical experiences they have experienced, the change that mystical experiences and mystical experiences generates in the individual, and the effects of mystical experiences and other religious life types on the religious life of the individual in accordance with the data of the psychology of religion".

As can be seen in the definition above, the field of Sufi psychology should focus on the motivations that lead one to Sufism, the mystical experiences of those who adopts Sufism, the change that occurs by Sufism, and how Sufism affects the general form of religiousness. These categories include subjects within the boundaries of the psychology of religion.

Research and analysis of religious experience and the psychology of Sufism is only possible through the use of some subjective techniques such as internal observation'. Today, the study of the experiential dimension of religion and the psychology of Sufism depends on the examination of the sensitive feelings of the believing individual. But; it is not possible to examine these emotions with quantitative techniques such as questionnaire and scale. In-depth interviewing method, which is a more appropriate for qualitative research techniques, can be used in order to one's internal observation and to overcome difficulties during the research.

As a conclusion, in this study, the current situation of Sufi psychology, concepts of religious-mystical and Sufi experience and the relationship between Sufi psychology and the experiential dimension of religiosity are revealed. At the same time, the boundaries of the psychology of Sufism are redrawn and a new definition is offered to be used in the studies of psychology of religion. 